\title{
Hypothesis: Selection of Imprinted Genes Is Driven by Silencing Deleterious Gene Activity in Somatic Tissues
}

\author{
F. Berger, T.M. Vu, J. Li, AND B. Chen \\ Temasek Lifesciences Laboratory, National University of Singapore, 117604 Singapore; Department \\ of Biological Sciences, National University of Singapore, 117543 Singapore \\ Correspondence: fred@tll.org.sg
}

\begin{abstract}
In mammals and plants, parental genomic imprinting restricts expression of certain loci to one parental allele. In mammals, imprinted genes affect various aspects of maternal care and nutrition of offspring from embryogenesis until adulthood. In plants, the expression of imprinted genes is mostly restricted to the endosperm, which nurtures the embryo. Although this restricted domain of expression suggests that the selection of imprinted genes is related to their role in endosperm, supporting evidence is still limited. In contrast, our literature survey supports a significant impact of ectopic expression of imprinted genes on vegetative tissues that affects plant fitness. We propose that silencing of gene function in vegetative tissue is the primary cause of selection of imprinted genes that may be followed by acquisition of major roles in seed development.
\end{abstract}

Parental genomic imprinting is an epigenetic regulation that causes preferential expression of certain loci to one parental allele (Feil and Berger 2007; Bartolomei 2009; Ferguson-Smith 2011). In mammals, sex-dependent de novo deposition of DNA methylation by specific methyltransferases Dnmt3a and Dnmt3b affects imprinted loci during male or female gametogenesis leading to asymmetric patterns of DNA methylation, which differentiate parental alleles and are further preserved in the embryo by the maintenance of DNA methyltransferase Dnmt1 (Bartolomei 2009; Ferguson-Smith 2011). In contrast, the plant homolog of Dnmt1, the DNA methyltransferase 1 (MET1), and the DNA demethylase DEMETER (DME) control parent-specific gene activation leading to imprinted expression after fertilization (Kohler and WeinhoferMolisch 2011; Wollmann and Berger 2012). Histone methylation by the Polycomb group also assists imprinting both in plants and mammals (Feil and Berger 2007).

Plant sexual reproduction involves two parallel fertilization events (Berger et al. 2008). Two sperm cells fertilize two distinct female gametes, the egg cell and the central cell, producing the embryo and the endosperm, respectively. The endosperm nurtures embryogenesis during seed development (Li and Berger 2012). Genomewide surveys of parental allele-specific expression in $\mathrm{Ara}$ bidopsis, rice, and maize have shown that imprinting is largely confined to genes expressed in endosperm (Gehring et al. 2011; Hsieh et al. 2011; Luo et al. 2011; Waters et al. 2011; Wolff et al. 2011; Zhang et al. 2011). Although a few genes show imprinted expression in the embryo in rice and maize (Luo et al. 2011; Waters et al. 2011; Zhang et al. 2011) and likely Arabidopsis (Nodine and Bartel 2011), this status is transient and to date there has been no report of imprinted expression in plants after seed germination. Hence, unlike mammals in which imprinting affects expression in adult tissues, plant-imprinted genes are expressed only during a limited period after fertilization.

How imprinting evolved remains unknown, but it is striking that both in plants and mammals imprinting impacts the endosperm and the placenta, respectively, dedicated to nutrition of the developing embryo. It was logical to hypothesize that the function of imprinted genes in the embryo-nurturing annexes played a major role in the evolution and selection of imprinting (Constancia et al. 2004; Charalambous et al. 2007; Berger and Chaudhury 2009; Kohler and Weinhofer-Molisch 2011). Some of these considerations led to the parental conflict theory, which predicts a positive selection of maternally expressed growth inhibitors and paternally expressed growth enhancers (Wilkins and Haig 2003; Haig 2004; Haig and Wilczek 2006). This theory is based on a scenario in which the mother contributes large resources to her offspring from different fathers. Embryos carrying different paternal genomes compete for resource allocation from the mother. It is beneficial for each father to deviate as many maternal resources as possible for his own embryos. It is thus advantageous for the mother to prevent such interference from the father to ensure equitable distribution of nutrients to each of her offspring.

Parental conflict theory suffers several shortcomings (de Jong and Scott 2007; Ferguson-Smith 2011; Li and Berger 2012). It applies to certain mammalian and outcrossing plant species but would not apply to self-fertilizing Arabidopsis, in which imprinting, nonetheless is found to be active. Parental conflict theory also predicts that maternally expressed imprinted genes should negatively regulate endosperm growth. Although this is the 
case for imprinted genes MEDEA (MEA) and FERTILIZATION INDEPENDENT SEED 2 (FIS2) (Gehring et al. 2004; Kohler and Weinhofer-Molisch 2011), the actin nucleator FORMIN HOMOLOGY 5 in Arabidopsis (Fitz Gerald et al. 2009) and the gene Maternally Expressed Gene 1 in maize (Costa et al. 2012) have effects opposite to that predicted by parental conflict theory. Among recently identified imprinted genes, very few show a function linked with growth regulation (Gehring et al. 2011; Hsieh et al. 2011; Luo et al. 2011; Waters et al. 2011; Wolff et al. 2011; Zhang et al. 2011). And contrary to the expectation of parental conflict theory, the genome-wide census of imprinted genes in Arabidopsis, rice, and maize showed limited conservation among related genes or even functional classes. One exceptional major example of conservation appears to be that imprinting affects genes encoding components of Polycomb repressive complex 2 (PRC2) including MEDEA (Li and Berger 2012). However, $M E A$ has not been subjected to a strong positive selection in Arabidopsis (Kawabe et al. 2007; Spillane et al. 2007; Miyake et al. 2009). Similarly, no positive selection was detected for the MEA maize homolog Mez1 (Haun et al. 2007). Together with the lack of obvious function of several imprinted genes identified in Arabidopsis, these facts question the hypothesis that the selection of imprinted genes operate by their functions in endosperm. Here, we report that silencing imprinted genes in somatic tissues is essential for a significant proportion of imprinted genes. We further propose a new hypothesis to explain the origin of the primary selection of imprinted genes.

\section{LIMITED IMPACT OF IMPRINTED GENES ON SEED DEVELOPMENT}

We compiled three lists of candidate imprinted genes obtained from genome-wide studies of transcriptomes from crosses among different wild-type accessions of Arabidopsis (Gehring et al. 2011; Hsieh et al. 2011; Wolff et al. 2011). The relative lack of overlap among the three lists is likely explained by the different accessions used, the different stages of seed development, and the relative amount of endosperm versus remaining surrounding tissues (seed coat) in the samples. We restricted the lists to maternally expressed candidate imprinted genes that showed a highly enriched expression in early endosperm (Le et al. 2011) and did not show expression in vegetative tissue (Schmid et al. 2005). We thus aimed to compile genes with temporal and spatial expression profiles that are similar to widely studied imprinted genes MEA, FIS2, and FWA (Table 1). To test for the similarity of expression pattern among selected genes, we applied a K-means algorithm (Herwig et al. 1999) to the Arabidopsis plant life-cycle transcriptome data set (Schmid et al. 2005). All genes presented in the ATH1 array are clustered into 15 groups based on their expression similarity. Among 26 imprinted genes, 19 imprinting genes could be clustered in two groups (both $P$ values are $<<0.0001$ ) (Fig. 1). One group contains MEA and FIS2, with a rel- atively longer expression during endosperm development (Fig. 1, top panel). The other group contains FWA and other genes encoding transcription factors from the AGAMOUS-LIKE families with a relatively shorter expression during the early syncytial (noncellular) phase of endosperm development (Fig. 1, bottom panel).

We further explored reports related to all selected imprinted genes relative to their functions. We found only very limited evidence relating to functions in the seed (Table 1). The effect of MEA and FIS2 on endosperm development has been extensively characterized. $M E A$ and FIS2 act in a Polycomb repressive complex, which represses expression of several genes expressed in endosperm and controls growth, temporal development, and patterning (Luo et al. 2000; Ingouff et al. 2005; Weinhofer et al. 2011). Maternal effects on seed development have been reported for MEE27 (Pagnussat et al. 2005) and MPC (Tiwari et al. 2008) but their exact role remains unknown. We did not find evidence in the current literature for major function in seeds for other maternally expressed imprinted genes. Similarly in maize (Waters et al. 2011; Zhang et al. 2011) and rice (Luo et al. 2011), although hundreds of candidate imprinted genes have been detected, there is still limited evidence to suggest an important role of imprinted genes in seeds ( $\mathrm{Li}$ and Berger 2012).

\section{IMPACT OF ECTOPIC EXPRESSION OF IMPRINTED GENES ON VEGETATIVE DEVELOPMENT}

Although neither $F W A$ nor $S D C$ play obvious roles in endosperm (F Berger et al., unpubl.), both genes affect vegetative development. Ectopic expression of demethylated alleles of $F W A$ delays flowering owing to the interaction between FWA and FLOWERING LOCUS T (FT) (Ikeda et al. 2007). Similarly, ectopic expression of $S D C$ perturbs leaf development and plant growth (Henderson and Jacobsen 2008). We thus searched for detailed studies reporting the impact of ectopic expression of other imprinted genes from our selected list.

Opposite to $F W A$ ectopic expression, overexpression of the JmjC-domain-containing H3K4 demethylase JMJ15 caused early flowering (Yang et al. 2012). JMJ15 is a member of the H3K4 demethylase JARID1 family and displays H3K4me3 demethylase activity. The mutation of $J M J 15$ does not produce an obvious phenotype. In contrast, overexpression of JMJ15 reduces H3K4me3 at the $F L C$ locus and represses $F L C$ transcript levels, resulting in increased $F T$ expression and precocious flowering. Similarly, AtBMIIC overexpression causes early flowering in Arabidopsis via silencing of the flowering repressor $F L C$ and by promoting expression of the flowering activator $F T$ (Li et al. 2011). AtBMIIC is a component of a PRC1-like complex that shows H2A monoubiquitination activity. Early flowering also results from overexpression of AGAMOUS LIKE 28 (AGL28), but the pathway involved is independent of $F T$ and FLC. AGL28 up-regulates the expression of FCA and LUMINIDEPENDENS 
Table 1. Survey of imprinted genes and their effect on seed and vegetative development

\begin{tabular}{|c|c|c|c|c|c|}
\hline Gene ID & Gene name & Function & Seed-specific expression? & $\begin{array}{l}\text { Deleterious if } \\
\text { ectopically } \\
\text { expressed? }\end{array}$ & $\begin{array}{c}\text { Effect on } \\
\text { endosperm/ } \\
\text { seed? }\end{array}$ \\
\hline AT1G69520 & & Methyltransferase & & & \\
\hline AT5G42930 & & Lipid metabolism & & & \\
\hline AT2G17690 & $S D C$ & Unknown & Yes & Yes & No \\
\hline AT4G00220 & $J L O$ & Lob domain & Yes & Yes & \\
\hline AT4G31060 & ERF015 & AP2 TF & Yes & Yes? & \\
\hline AT1G20500 & $G A M T 1$ & Gibberelin metabolism & Yes & Yes & \\
\hline AT1G62333 & & Unknown & & & \\
\hline AT1G34060 & & Secondary metabolism & & & \\
\hline AT3G49540 & & Unknown & & & \\
\hline AT3G16720 & ATL2 & Response to pathogens & & Yes & \\
\hline AT1G14580 & & $\mathrm{Zn}$-finger protein & No, but higher in seed & & \\
\hline AT4G23020 & TRM11 & Microtubule associated? & & & \\
\hline AT1G73500 & MAPKK9 & MAPKK response to pathogen & No, but increases in seed & Yes & \\
\hline AT5G22020 & & Strictosidine synthetase & & & \\
\hline AT5G64430 & & Unknown & & & \\
\hline AT2G38250 & $\mathrm{SRO} 3$ & TF response to pathogen & More, but low & & \\
\hline AT1G27730 & & Response to stress $\mathrm{Zn}$ finger & No, but higher in seed & & \\
\hline AT5G26700 & & Response to pathogen & & & \\
\hline AT1G02580 & $M E A$ & Chromatin modification & Yes & Yes? & Yes \\
\hline AT2G35670 & FIS2 & Chromatin modification & Yes & Yes? & Yes \\
\hline AT3G03260 & $H D G 8$ & $\mathrm{TF}$ & Yes & & \\
\hline AT3G19350 & $M P C$ & & Yes & & $?$ \\
\hline AT4G00540 & $M Y B 3 R 2$ & myb TF & & Yes & \\
\hline AT4G25530 & $F W A / H D G 6$ & Homeodomain $\mathrm{TF}$ & Yes & Yes & No \\
\hline AT5G17321 & & Homeodomain TF? & Yes & & \\
\hline AT5G17322 & $J M J 15$ & dsRNA binding/miRNA function & Yes & Yes & Yes? \\
\hline AT5G17323 & SUVH8 & Set domain & Yes & & \\
\hline AT5G17324 & SUVH7 & Set domain & & & \\
\hline AT5G17325 & & Nodulin-like transporter & Yes & & \\
\hline AT1G52460 & & Hydrolase & Yes & & \\
\hline AT3G23060 & BMIIC & Zn-finger PRC1 & Yes & Yes & \\
\hline AT5G03020 & & Keltch domain & $?$ & & \\
\hline AT1G60970 & & SNARE-like & $?$ & $\begin{array}{l}\text { Link with cytokinin; } \\
\text { link with pathogen } \\
\text { disease resistance }\end{array}$ & \\
\hline AT2G19400 & $A G C$ & ser/Thr protein kinase & & & \\
\hline AT4G29570 & & Cytidine deaminase & & & \\
\hline AT5G46300 & & Unknown & Yes & & \\
\hline AT3G10590 & & Homeodomain & Yes? & & \\
\hline AT3G21830 & $A S K 8$ & Interact with F-box proteins & & & \\
\hline AT1G51000 & & Unknown & & & \\
\hline AT5G26650 & $A G L 36$ & $\mathrm{TF}$ & Yes & & \\
\hline AT1G01530 & $A G L 28$ & TF & No, but increases in seed & Yes & \\
\hline AT5G06500 & AGL96 & TF & Yes? & & \\
\hline AT1G20730 & & Unknown & Yes? & & \\
\hline
\end{tabular}

(LD) within the autonomous pathway (Yoo et al. 2006). In addition to these four imprinted genes that impact flowering time via three different pathways, misexpression of the MYB transcription factor MYB3R2 confers aberrant circadian rhythms that also impact the plant developmental temporal program (Hanano et al. 2008). In conclusion, repression of at least five imprinted genes is required to program proper flowering time in Arabidopsis.

Similarly to results with $S D C$, we found reports providing evidence that overexpression of two other maternally expressed imprinted genes affects plant morphological development. GAMT1 is involved in methylation of gibberelins and its overexpression hampers plant development (Varbanova et al. 2007). Plants produce rosettes of slow-growing little downward-curved dark green leaves and abnormal flowers with reduced reproductive organs, leading to a degree of sterility. Similarly, the JAGGED LATERAL ORGANS (JLO) gene, which encodes a member of the LATERAL ORGAN BOUNDARY DOMAIN proteins, affects the activity of another plant hormone, auxin. Inducible $J L O$ misexpression activates expression of the KNOX genes SHOOT MERISTEMLESS and KNAT1 in leaves and down-regulates the expression of PIN auxin export facilitators (Borghi et al. 2007). Consequently, bulk auxin transport through the inflorescence stem is drastically reduced, resulting in strongly lobed leaves and termination of the shoot apical meristem with a pin-like phenotype. Vegetative plant development is thus influenced by imprinted genes if they are ectopically expressed. PRC2 is a major regulator of several aspects of plant development. Arabidopsis PRC2 imprinted genes $M E A$ and FIS2 belong to two families containing two other genes. MEA homologs SWINGER 

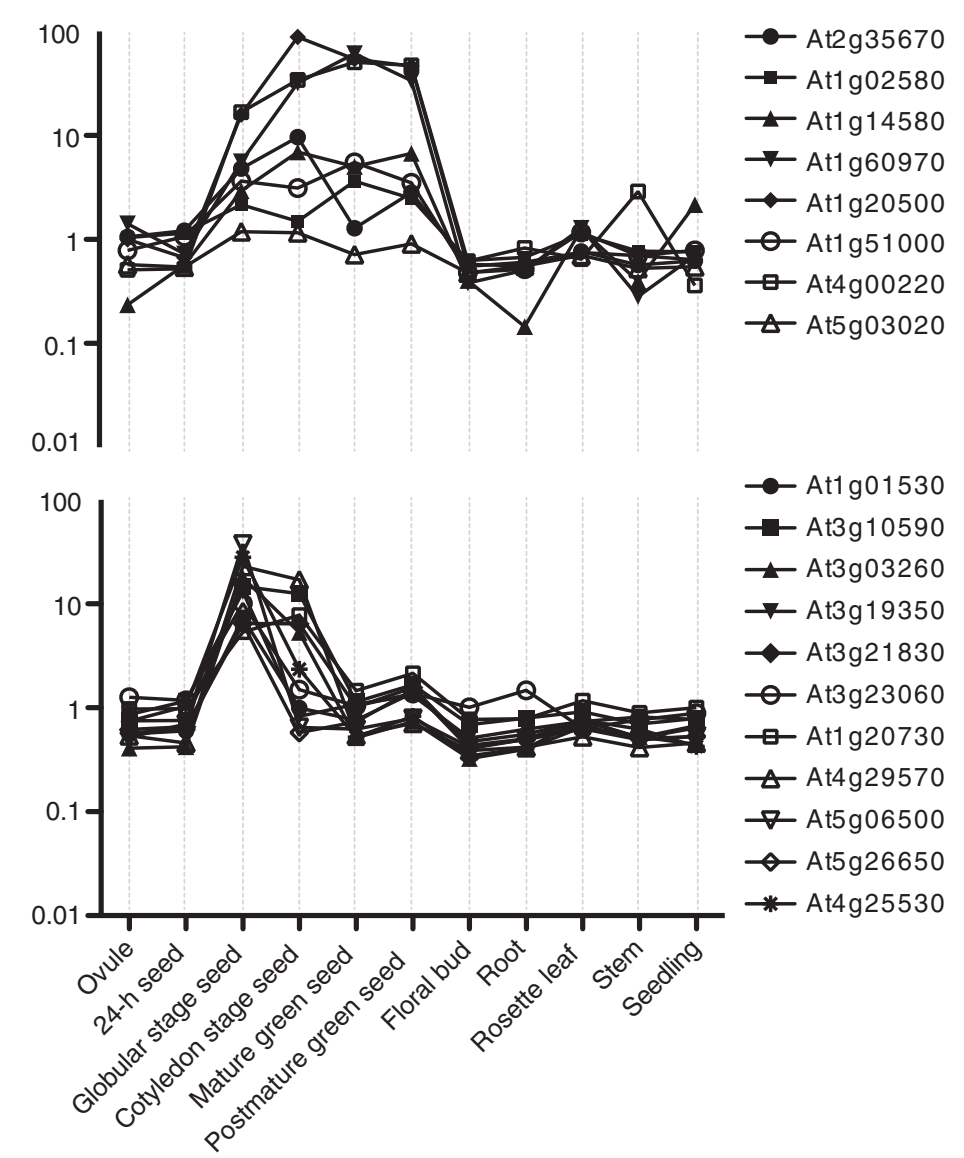

Figure 1. Imprinting genes are enriched in two K-means cluster groups. The $y$ axis shows normalized intensity (log scale). At $2 \mathrm{~g} 35670$ encodes FIS2, At1g02580 encodes MEA, and At4g25530 encodes FWA.

$(S W N)$ and CURLY LEAF $(C L F)$ and FIS2 homologs VERNALIZATION2 (VERN2) and EMBRYONIC FLOW$E R 2$ (EMF2) are expressed in vegetative tissues and act in a partially redundant manner (Hennig and Derkacheva 2009; Holec and Berger 2012). It is likely that additional dosage of PRC2 caused by ectopic expression of MEA or FIS2 in vegetative tissue would perturb PRC2 function, although this remains to be tested.

In conclusion, we observed that ectopic expression of several imprinted genes caused various types of deleterious effects on plant development. Our analysis reveals that a third class of imprinted genes is associated with plant defense and response to stress. Among the ETHYLENE RESPONSE FACTOR (ERF) gene family, AtERF015 is linked to AtERF2, which when overexpressed in transgenic Arabidopsis plants activated transcription from genes encoding basic chitinase, suggesting hyperactivation of plant defense (Brown et al. 2003). Similarly, ARABIDOPSIS TOXICOS EN LEVADURA 2 (ATL2) is involved in response to elicitors such as chitin (Serrano and Guzman 2004). ATL2 is a member of a multigene family coding highly related RING-H2 zincfinger proteins that may function as E3 ubiquitin ligases. Constitute expression of ATL2 causes activation of two early chitin-induced genes and known pathogenesis-related genes that are markers of the salicylic acid
(SA) and jasmonate (JA) defense response. In the field, priming of SA-related defense responses significantly increases disease resistance and plant fitness (Traw et al. 2007) but reduces fitness in the absence of pathogens, as determined in laboratory growth conditions (Abreu and Munne-Bosch 2009). Also related to plant defense mechanisms, the mitogen-activated protein kinase (MPK) cascades play important roles in regulating plant growth, development, and responses to various environmental stimuli (Pitzschke et al. 2009; Zhang and Zhou 2010). Ectopic expression of the imprinted gene MKK9 in transgenic plants induces the synthesis of ethylene and camalexin through the activation of the endogenous MPK 3 and MPK6 kinases and enhances the sensitivity of transgenic seedlings to biotic stress (Xu et al. 2008).

\section{DISCUSSION AND HYPOTHESES}

Our survey identifies a class of maternally expressed imprinted genes displaying expression patterns similar to classically studied genes $M E A$ and $F W A$. When expressed ectopically in vegetative tissues, more than $25 \%$ of these 43 imprinted genes were shown to affect plant life in a manner that is likely deleterious for plant fitness. These genes belong to three functional classes, a class with 
broad impact on plant development linked to a role in hormones or in chromatin regulation, a second class of regulators of flowering, and a third class related to response to pathogens. Reports regarding the effect of ectopic expression are missing for the remaining $75 \%$ of genes surveyed. Most genes studied so far belong to families comprising several homologs expressed in vegetative tissues. It is thus intriguing that ectopic expression of an additional member of a family has an impact and we can hypothesize that this results from either an imbalance of dosage or that imprinted genes encode proteins that cause dominant negative effects when competing for formation of complexes that involve other members of the family. We conclude that silencing imprinted genes in vegetative tissues is beneficial for plant development and fitness. In contrast, a function in seed development was shown only for a few imprinted genes in Arabidopsis. These observations suggest that it is more essential to keep imprinted loci silent in vegetative tissues to ensure proper plant development than to ensure their function during endosperm development.

We propose that silencing is the primary event that is selected and leads to imprinted expression. What mediates the initial silencing? The frequent association of transposons to imprinted genes in plants may provide a mechanism to explain the origin of methylation of cis elements that would initiate silencing of new imprinted loci (Walter and Paulsen 2003; Okamura et al. 2004; Wilkins 2005; Fujimoto et al. 2008; Hsieh et al. 2011; Kaneko-Ishino and Ishino 2011; McCole et al. 2011; Wolff et al. 2011). In plants, although the mechanism that silences transposons-RNA-directed DNA methylation (RdDM) (Saze and Kakutani 2007; Martienssen et al. 2008; Mirouze et al. 2009) - is not associated with imprinting (Wollmann and Berger 2012), recent reports have suggested that RdDM is active in pollen on imprinted loci (Calarco et al. 2012), suggesting a role of de novo DNA methylation in imprinting, which still needs to be shown.

How would silencing by DNA methylation result in imprinted expression during seed development? Several key members of the DNA methylation pathway are repressed in the female gametes but are active in the male gametes, and this repression is required for activation of imprinted genes in the central cell (Jullien et al. 2008, 2012). In addition the DNA demethylase DEMETER (DME) expressed in the central cell plays an important additional role for the activation of maternal alleles of imprinted genes (Gehring et al. 2004). The conjunction of both mechanisms results in demethylation of the central cell, which still remains to be confirmed directly, whereas DNA methylation on $\mathrm{CG}$ and $\mathrm{CHG}$ is maintained in male gametes (Calarco et al. 2012). For our hypothesis, we consider loci that are expressed from both alleles in endosperm in an ancestral state. According to the supposed imbalance of general status of DNA methylation between male and female gametes, any event causing silencing by DNA methylation of such a locus results in maternal expression. In more complex cases, demethylation of cis elements may impact paternal expression, as shown for the paternally expressed imprinted gene PHERES1 (Makarevich et al. 2008). We propose that results of the initial silencing event from neoproduction of siRNAs (small interfering RNA) would attract DNA methylation de novo. This can result from transposition but also from many other events such as gene duplications, events leading to initiation of antisense transcripts, deletion, or insertions. We assume that the methylated locus includes sufficient numbers of $\mathrm{CG}$ and $\mathrm{CHG}$ residues that allow the DNA methylation pattern to be inherited through cell division in a semiconservative manner by the maintenance of DNA methyltransferases MET1 and CMT3. If the effect of the methylated cis element is beneficial or neutral for the plant vegetative development, the new event is retained and selected positively. The gene then becomes expressed only in the endosperm from the parental allele that retains the epigenetic methylation marks removed differentially during gametogenesis. In rare cases, the gene acquires a positive function for endosperm and seed development, and its mutation causes a maternal gametophytic effect such as that shown for $M E A$ and FIS2. In other cases, the function of imprinted genes in endosperm might not be of importance, which would explain the lack of conservation of imprinting genes across species.

\section{ACKNOWLEDGMENTS}

F.B., T.M.V., and J.L. are funded by Temasek Lifesciences Laboratory.

\section{REFERENCES}

Abreu ME, Munne-Bosch S. 2009. Salicylic acid deficiency in $\mathrm{NahG}$ transgenic lines and sid 2 mutants increases seed yield in the annual plant Arabidopsis thaliana. J Exp Bot 60: 12611271.

Bartolomei MS. 2009. Genomic imprinting: Employing and avoiding epigenetic processes. Genes Dev 23: 2124-2133.

Berger F, Chaudhury A. 2009. Parental memories shape seeds. Trends Plant Sci 14: 550-556.

Berger F, Hamamura Y, Ingouff M, Higashiyama T. 2008. Double fertilization - caught in the act. Trends Plant Sci 13: 437443.

Borghi L, Bureau M, Simon R. 2007. Arabidopsis JAGGED LATERAL ORGANS is expressed in boundaries and coordinates KNOX and PIN activity. Plant Cell 19: 1795-1808.

Brown RL, Kazan K, McGrath KC, Maclean DJ, Manners JM. 2003. A role for the GCC-box in jasmonate-mediated activation of the PDF1.2 gene of Arabidopsis. Plant Physiol 132: $1020-1032$.

Calarco JP, Borges F, Donoghue MT, Van Ex F, Jullien PE, Lopes T, Gardner R, Berger F, Feijo JA, Becker JD, et al. 2012. Reprogramming of DNA Methylation in Pollen Guides Epigenetic Inheritance via Small RNA. Cell 151: 194-205.

Charalambous M, da Rocha ST, Ferguson-Smith AC. 2007. Genomic imprinting, growth control and the allocation of nutritional resources: Consequences for postnatal life. Curr Opin Endocrinol Diabetes Obes 14: 3-12.

Constancia M, Kelsey G, Reik W. 2004. Resourceful imprinting. Nature 432: $53-57$.

Costa LM, Yuan J, Rouster J, Paul W, Dickinson H, GutierrezMarcos JF. 2012. Maternal control of nutrient allocation in plant seeds by genomic imprinting. Curr Biol 22: 160-165.

de Jong TJ, Scott RJ. 2007. Parental conflict does not necessarily lead to the evolution of imprinting. Trends Plant Sci 12: 439443 . 
Feil R, Berger F. 2007. Convergent evolution of genomic imprinting in plants and mammals. Trends Genet 23: 192-199.

Ferguson-Smith AC. 2011. Genomic imprinting: The emergence of an epigenetic paradigm. Nat Rev Genet 12: 565575.

Fitz Gerald JN, Hui PS, Berger F. 2009. Polycomb group-dependent imprinting of the actin regulator AtFH5 regulates morphogenesis in Arabidopsis thaliana. Development 136: 3399-3404.

Fujimoto R, Kinoshita Y, Kawabe A, Kinoshita T, Takashima K, Nordborg M, Nasrallah ME, Shimizu KK, Kudoh H, Kakutani T. 2008. Evolution and control of imprinted $F W A$ genes in the genus Arabidopsis. PLoS Genet 4: e1000048.

Gehring M, Choi Y, Fischer RL. 2004. Imprinting and seed development. Plant Cell 16 Suppl: S203-S213.

Gehring M, Missirian V, Henikoff S. 2011. Genomic Analysis of Parent-of-Origin Allelic Expression in Arabidopsis thaliana Seeds. PLoS One 6: e23687.

Haig D. 2004. Genomic imprinting and kinship: How good is the evidence? Annu Rev Genet 38: 553-585.

Haig D, Wilczek A. 2006. Sexual conflict and the alternation of haploid and diploid generations. Philos Trans R Soc Lond B Biol Sci 361: 335-343.

Hanano S, Stracke R, Jakoby M, Merkle T, Domagalska MA, Weisshaar B, Davis SJ. 2008. A systematic survey in Arabidopsis thaliana of transcription factors that modulate circadian parameters. BMC Genomics 9: 182.

Haun WJ, Laoueille-Duprat S, O'Connell MJ, Spillane C, Grossniklaus U, Phillips AR, Kaeppler SM, Springer NM. 2007. Genomic imprinting, methylation and molecular evolution of maize Enhancer of zeste (Mez) homologs. Plant $J$ 49: $325-337$

Henderson IR, Jacobsen SE. 2008. Tandem repeats upstream of the Arabidopsis endogene SDC recruit non-CG DNA methylation and initiate siRNA spreading. Genes Dev 22: 15971606.

Hennig L, Derkacheva M. 2009. Diversity of Polycomb group complexes in plants: Same rules, different players? Trends Genet 25: 414-423.

Herwig R, Poustka AJ, Muller C, Bull C, Lehrach H, O'Brien J. 1999. Large-scale clustering of cDNA-fingerprinting data. Genome Res 9: 1093-1105.

Holec S, Berger F. 2012. Polycomb group complexes mediate developmental transitions in plants. Plant Physiol 158: 35-43.

Hsieh TF, Shin J, Uzawa R, Silva P, Cohen S, Bauer MJ, Hashimoto M, Kirkbride RC, Harada JJ, Zilberman D, et al. 2011. Regulation of imprinted gene expression in Arabidopsis endosperm. Proc Natl Acad Sci 108: 1755-1762.

Ikeda Y, Kobayashi Y, Yamaguchi A, Abe M, Araki T. 2007. Molecular basis of late-flowering phenotype caused by dominant epi-alleles of the FWA locus in Arabidopsis. Plant Cell Physiol 48: 205-220.

Ingouff M, Haseloff J, Berger F. 2005. Polycomb group genes control developmental timing of endosperm. Plant $J$ 42: 663-674.

Jullien PE, Mosquna A, Ingouff M, Sakata T, Ohad N, Berger F. 2008. Retinoblastoma and its binding partner MSI1 control imprinting in Arabidopsis. PLoS Biol 6: e194.

Jullien PE, Susaki D, Yelagandula R, Higashiyama T, Berger F. 2012. DNA Methylation Dynamics during Sexual Reproduction in Arabidopsis thaliana. Curr Biol 22: 1825-1830.

Kaneko-Ishino T, Ishino F. 2011. Retrotransposon silencing by DNA methylation contributed to the evolution of placentation and genomic imprinting in mammals. Dev Growth Differ 52: $533-543$.

Kawabe A, Fujimoto R, Charlesworth D. 2007. High diversity due to balancing selection in the promoter region of the $\mathrm{Me}$ dea gene in Arabidopsis lyrata. Curr Biol 17: 1885-1889.

Kohler C, Weinhofer-Molisch I. 2011. Mechanisms and evolution of genomic imprinting in plants. Heredity 105: 57-63.

Le BH, Cheng C, Bui AQ, Wagmaister JA, Henry KF, Pelletier J, Kwong L, Belmonte M, Kirkbride R, Horvath S, et al. 2011. Global analysis of gene activity during Arabidopsis seed development and identification of seed-specific transcription factors. Proc Natl Acad Sci 107: 8063-8070.

Li J, Berger F. 2012. Endosperm: Food for humankind and fodder for scientific discoveries. New Phytol 195: 290-305.

Li W, Wang Z, Li J, Yang H, Cui S, Wang X, Ma L. 2011. Overexpression of AtBMIIC, a Polycomb group protein gene, accelerates flowering in Arabidopsis. PLoS One 6: e21364.

Luo M, Bilodeau P, Dennis ES, Peacock WJ, Chaudhury A. 2000. Expression and parent-of-origin effects for FIS2, $M E A$, and FIE in the endosperm and embryo of developing Arabidopsis seeds. Proc Natl Acad Sci 97: 10637-10642.

Luo M, Taylor JM, Spriggs A, Zhang H, Wu X, Russell S, Singh M, Koltunow A. 2011. A genome-wide survey of imprinted genes in rice seeds reveals imprinting primarily occurs in the endosperm. PLoS Genet 7: e1002125.

Makarevich G, Villar CB, Erilova A, Kohler C. 2008. Mechanism of PHERES1 imprinting in Arabidopsis. J Cell Sci 121: 906-912.

Martienssen RA, Kloc A, Slotkin RK, Tanurdzic M. 2008. Epigenetic inheritance and reprogramming in plants and fission yeast. Cold Spring Harb Symp Quant Biol 73: 265-271.

McCole RB, Loughran NB, Chahal M, Fernandes LP, Roberts RG, Fraternali F, O’Connell MJ, Oakey RJ. 2011. A case-bycase evolutionary analysis of four imprinted retrogenes. Evolution 65: 1413-1427.

Mirouze M, Reinders J, Bucher E, Nishimura T, Schneeberger K, Ossowski S, Cao J, Weigel D, Paszkowski J, Mathieu O. 2009. Selective epigenetic control of retrotransposition in Arabidopsis. Nature 461: 427-430.

Miyake T, Takebayashi N, Wolf DE. 2009. Possible diversifying selection in the imprinted gene, MEDEA, in Arabidopsis. Mol Biol Evol 26: $843-857$.

Nodine MD, Bartel DP. 2011. Maternal and paternal genomes contribute equally to the transcriptome of early plant embryos. Nature 482: 94-97.

Okamura K, Yamada Y, Sakaki Y, Ito T. 2004. An evolutionary scenario for genomic imprinting of Impact lying between nonimprinted neighbors. DNA Res 11: 381-390.

Pagnussat GC, Yu HJ, Ngo QA, Rajani S, Mayalagu S, Johnson CS, Capron A, Xie LF, Ye D, Sundaresan V. 2005. Genetic and molecular identification of genes required for female gametophyte development and function in Arabidopsis. Development 132: $603-614$.

Pitzschke A, Schikora A, Hirt H. 2009. MAPK cascade signalling networks in plant defence. Curr Opin Plant Biol 12: 421-426.

Saze H, Kakutani T. 2007. Heritable epigenetic mutation of a transposon-flanked Arabidopsis gene due to lack of the chromatin-remodeling factor DDM1. EMBO J 26: 3641-3652.

Schmid M, Davison TS, Henz SR, Pape UJ, Demar M, Vingron M, Scholkopf B, Weigel D, Lohmann JU. 2005. A gene expression map of Arabidopsis thaliana development. Nat Genet 37: 501-506.

Serrano M, Guzman P. 2004. Isolation and gene expression analysis of Arabidopsis thaliana mutants with constitutive expression of $A T L 2$, an early elicitor-response RING-H2 zinc-finger gene. Genetics 167: 919-929.

Spillane C, Schmid KJ, Laoueille-Duprat S, Pien S, EscobarRestrepo JM, Baroux C, Gagliardini V, Page DR, Wolfe KH, Grossniklaus U. 2007. Positive darwinian selection at the imprinted MEDEA locus in plants. Nature 448: 349-352.

Tiwari S, Schulz R, Ikeda Y, Dytham L, Bravo J, Mathers L, Spielman M, Guzman P, Oakey RJ, Kinoshita T, et al. 2008. MATERNALLY EXPRESSED PAB C-TERMINAL, a novel imprinted gene in Arabidopsis, encodes the conserved C-terminal domain of polyadenylate binding proteins. Plant Cell 20: $2387-2398$.

Traw MB, Kniskern JM, Bergelson J. 2007. SAR increases fitness of Arabidopsis thaliana in the presence of natural bacterial pathogens. Evolution 61: 2444-2449.

Varbanova M, Yamaguchi S, Yang Y, McKelvey K, Hanada A, Borochov R, Yu F, Jikumaru Y, Ross J, Cortes D, et al. 2007. Methylation of gibberellins by Arabidopsis GAMT1 and GAMT2. Plant Cell 19: 32-45. 


\section{SELECTION OF IMPRINTED GENES}

Walter J, Paulsen M. 2003. The potential role of gene duplications in the evolution of imprinting mechanisms. Hum Mol Genet 12 Spec No 2: R215-R220.

Waters AJ, Makarevitch I, Eichten SR, Swanson-Wagner RA, Yeh CT, Xu W, Schnable PS, Vaughn MW, Gehring M, Springer NM. 2011. Parent-of-origin effects on gene expression and DNA methylation in the maize endosperm. Plant Cell 23: 4221-4233.

Weinhofer I, Hehenberger E, Roszak P, Hennig L, Kohler C. 2011. H3K27me3 profiling of the endosperm implies exclusion of Polycomb group protein targeting by DNA methylation. PLoS Genet 6: e1001152.

Wilkins JF. 2005. Genomic imprinting and methylation: Epigenetic canalization and conflict. Trends Genet 21: 356-365.

Wilkins JF, Haig D. 2003. What good is genomic imprinting: The function of parent-specific gene expression. Nat Rev Genet 4: $359-368$.

Wolff P, Weinhofer I, Seguin J, Roszak P, Beisel C, Donoghue MT, Spillane C, Nordborg M, Rehmsmeier M, Kohler C. 2011. High-resolution analysis of parent-of-origin allelic expression in the Arabidopsis endosperm. PLoS Genet 7: e1002126.
Wollmann H, Berger F. 2012. Epigenetic reprogramming during plant reproduction and seed development. Curr Opin Plant Biol 15: 63-69.

Xu J, Li Y, Wang Y, Liu H, Lei L, Yang H, Liu G, Ren D. 2008. Activation of MAPK kinase 9 induces ethylene and camalexin biosynthesis and enhances sensitivity to salt stress in Arabidopsis. J Biol Chem 283: 26996-27006.

Yang H, Mo H, Fan D, Cao Y, Cui S, Ma L. 2012. Overexpression of a histone H3K4 demethylase, JMJ15, accelerates flowering time in Arabidopsis. Plant Cell Rep 31: 1297 1308.

Yoo SK, Lee JS, Ahn JH. 2006. Overexpression of AGAMOUSLIKE 28 (AGL28) promotes flowering by upregulating expression of floral promoters within the autonomous pathway. Biochem Biophys Res Commun 348: 929-936.

Zhang J, Zhou JM. 2010. Plant immunity triggered by microbial molecular signatures. Mol Plant 3: 783-793.

Zhang M, Zhao H, Xie S, Chen J, Xu Y, Wang K, Zhao H, Guan H, Hu X, Jiao Y, et al. 2011. Extensive, clustered parental imprinting of protein-coding and noncoding RNAs in developing maize endosperm. Proc Natl Acad Sci 108: 20042 20047. 


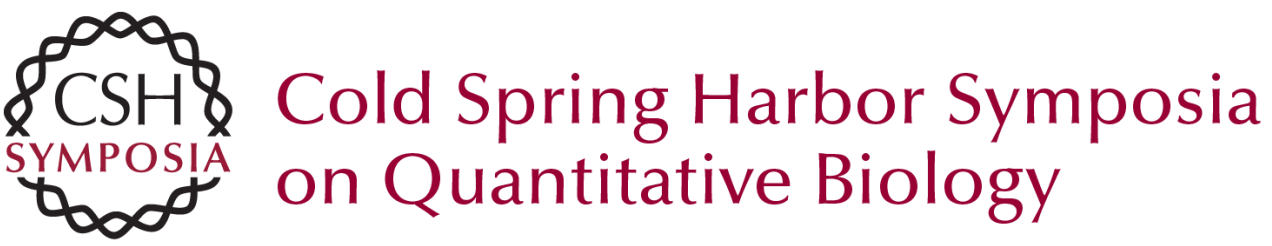

\section{Hypothesis: Selection of Imprinted Genes Is Driven by Silencing Deleterious Gene Activity in Somatic Tissues}

F. Berger, T.M. Vu, J. Li, et al.

Cold Spring Harb Symp Quant Biol 2012 77: 23-29 originally published online December 18, 2012

Access the most recent version at doi:10.1101/sqb.2012.77.014514

References This article cites 66 articles, 19 of which can be accessed free at: http://symposium.cshlp.org/content/77/23.full.html\#ref-list-1

\section{License}

Email Alerting Receive free email alerts when new articles cite this article - sign up in Service the box at the top right corner of the article or click here. 